\title{
Shark aggregation in coastal waters of British Columbia
}

\author{
Rob Williams ${ }^{1,2, *}$, Thomas A. Okey ${ }^{3,4}$, S. Scott Wallace $^{5}$, Vincent F. Gallucci ${ }^{6}$ \\ ${ }^{1}$ Marine Mammal Research Unit, Room 247, AERL, 2202 Main Mall, University of British Columbia, Vancouver, \\ British Columbia V6T 1Z4, Canada
}

${ }^{2}$ The Henry M. Jackson School of International Studies, University of Washington, Box 353650, Seattle, Washington 98195-3650, USA

${ }^{3}$ School of Environmental Studies, University of Victoria, PO Box 3060 STN CSC, Victoria, British Columbia V8W 3R4, Canada

${ }^{4}$ West Coast Aquatic, \#3 4310 10th Avenue, Port Alberni, British Columbia V9Y 4X4, Canada

${ }^{5}$ David Suzuki Foundation, 2211 West 4th Avenue, Vancouver, British Columbia V6K 4S2, Canada

${ }^{6}$ School of Aquatic and Fishery Sciences, University of Washington, Box 355020, Seattle, Washington 98195-5020, USA

\begin{abstract}
A concentration of pelagic sharks was observed in an area of western Queen Charlotte Sound, British Columbia, during systematic shipboard line-transect surveys conducted (2004 to 2006) for marine mammals throughout coastal waters of British Columbia. Surveys allowed only brief observations of sharks at the surface, providing limited opportunity to confirm species identity. Observers agreed, however, that salmon sharks Lamna ditropis (Lamnidae) were most common, followed by blue sharks Prionace glauca (Carcharhinidae). Both conventional and model-based distance sampling statistical methods produced large abundance estimates ( 20 000 sharks of all species combined) concentrated within a hotspot encompassing $\sim 10 \%$ of the survey region. Neither statistical method accounted for submerged animals, thereby underestimating abundance. Sightings were made in summer, corresponding with southern movement of pregnant salmon sharks from Alaska. The previously undocumented high density of these pelagic sharks in this location has implications for understanding at-sea mortality of returning Pacific salmon Oncorhynchus spp. (Salmonidae) and for assessing conservation status of sharks in Canada and beyond. We recommend that a dedicated Canada-US sightings and biological sampling programme be considered, perhaps under the UN Transboundary Species Fishery programme.
\end{abstract}

KEY WORDS: Abundance $\cdot$ Density $\cdot$ Distance sampling $\cdot$ Distribution $\cdot$ Elasmobranch $\cdot$ Line transect $\cdot$ Salmon mortality $\cdot$ Shark $\cdot$ Spatial model

Resale or republication not permitted without written consent of the publisher

\section{INTRODUCTION}

Shark populations in Canada's Pacific waters are poorly understood, and information on their population size and status is required to understand the role of top predators in marine ecosystems and to inform conservation and management efforts. Status assessments have not been pursued in Canada for many species due to insufficient information. On a global scale, salmon sharks Lamna ditropis are considered 'data deficient' by the International Union for Conservation of Nature (IUCN), and blue sharks Prionace glauca are currently listed as 'near threatened' due to large numbers being caught in unmanaged global fisheries (Stevens 2005). As a generalisation, stock assessments of shark populations are usually not practical except for those few species for which catch-effort data exist. Risk analyses may nevertheless be possible (Aires-da-Silva \& Gallucci 2007) as a substitute to estimate the probability of population declines below e.g. $50 \%$ of pre-exploitation levels or the estimation of a reference point of interest. Estimates of abundance are especially difficult to obtain and any information towards this end is valuable.

Salmon sharks are distributed throughout the subarctic North Pacific Ocean and north temperate Pacific Ocean waters. They inhabit the Gulf of Alaska and 
even parts of the Bering Sea at least during summer and autumn (Hulbert et al. 2005, Weng et al. 2005, 2008, Okey et al. 2007, Gallucci et al. 2008). Individuals tagged in Alaska during July and August migrated from summer coastal habitat (about $60^{\circ} \mathrm{N}$ latitude) southward throughout the northeast Pacific Ocean to about $28^{\circ} \mathrm{N}$ latitude and as far south as $22^{\circ} \mathrm{N}$ latitude near Hawai'i (Hulbert et al. 2005, Weng et al. 2005, 2008), though migration timing and routes varied considerably. Northward return apparently occurs during spring through autumn along the North American coast via British Columbia (BC). Tagged migrants were all female and likely to pup in productive waters south of the oceanic transition zone (Goldman 2003, Hulbert et al. 2005, Gallucci et al. 2008), including California coastal areas and offshore areas. In California waters, neonates apparently feed and grow for 1 or $2 \mathrm{yr}$, after which they begin to travel northward towards coastal $\mathrm{BC}$ and Alaska. Little is known about this stage of the life cycle or the true distribution of pupping. It is possible that salmon shark populations have increased in recent decades in the North Pacific, at least in particular areas (Okey et al. 2007), and they have the potential to consume large numbers of returning Pacific salmon (Nagasawa 1998, Hulbert \& Rice 2002, Hulbert et al. 2005, DeMaddalena et al. 2007, Okey et al. 2007). Despite the recent opening of a recreational salmon shark fishery in Alaska, basic demographic and related information about the species is unknown, some of which may be more easily or cost-effectively collected in areas in which sharks are found reliably in high numbers.

Some BC Coho and Chinook salmon stocks (Oncorhynchus kisutch and O. tshawytscha, respectively) appear to have declined relatively suddenly (i.e. since the early 1990s), while stocks of these species in Washington, Oregon and California have declined gradually (i.e. over an 83 yr time period) (based on catch data in Eggers et al. 2005). Sockeye salmon O. nerka have also recently exhibited signs of distress in $\mathrm{BC}_{\text {; }}$ e.g. the sockeye returns in the Fraser River were unexpectedly low in 2009. Explanations for declines in BC salmon stocks include changes in climate and oceanography (e.g. BCMWALP 2002, Brodeur et al. 2006, Battin et al. 2007, BCME 2007, Crozier et al. 2008), increased hatchery production (e.g. Hilborn 1992, NRC 1996, Waples 1999), increased open-net farming of Atlantic salmon in coastal BC and the associated transmission of parasitic salmon lice (e.g. Lepeophtheirus salmonis, Caligidae) (e.g. Krkosek et al. 2006, 2007), degradation of spawning habitat, poorly managed fisheries, and increased predation. A better understanding of factors influencing at-sea survival of salmon is needed; this is the central question of the ongoing Pacific Ocean Shelf Tracking Project. At-sea predators of salmon include marine mammals and sharks, but predation effects have received relatively little attention due to the challenges in studying them (Groot \& Margolis 1991).

A systematic, shipboard, sightings survey was designed (Thomas et al. 2007) and conducted (Williams \& Thomas 2007) to estimate summertime abundance and distribution of marine mammals in coastal waters of British Columbia. Line-transect surveys are widely used to estimate abundance of wildlife (Buckland et al. 2001), and have been used recently to estimate abundance of basking sharks Cetorhinus maximus off Canada's Atlantic coast to inform a conservation status assessment for the species (Campana et al. 2008). Sightings of sharks were recorded in the BC marine mammal survey (Williams \& Thomas 2007, 2009), but have not been reported previously. Here we describe an area of high shark density identified from that survey. We present 2 methods for generating tentative abundance estimates for sharks from the effort and sightings data, and consider hypotheses for this observed aggregation including resting, reproductive activity and feeding. Improving our understanding of abundance and diet of marine predators, including sharks, is fundamental for conservation and ecosystem-based management of Pacific marine ecosystems.

\section{MATERIALS AND METHODS}

Study design and field methods. Shipboard surveys for marine mammals for coastal waters of British Columbia were conducted during the summers of 2004 to 2006 and spring 2007. Field protocols required observers to record all sightings of sharks. The survey followed a systematic design, which has been described previously (Thomas et al. 2007), and observers followed standard line-transect survey field protocols (Williams \& Thomas 2007). Unlike mark-recapture methods, distance sampling methods make no assumption about the identity of individuals, but rather estimate the average number of animals in the study area at the time the survey was being conducted. In the unlikely event that a shark was seen on 2 transects, it is assumed that there is an equal probability of another shark being missed on both transects (Buckland et al. 2001, p. 253; Thomas et al. 2010).

The survey was completed as planned in the summers of 2004 and 2005, but not in 2006 due to funding constraints. The survey was also completed in May and June 2007, but no sharks were seen during the spring survey, and so that season's effort was excluded from the analysis. Consequently, the field effort resulted in a 'design-unbiased' (Buckland et al. 2001) sample for 2004 and 2005, but an unrepresentative sampling design for 2006. Consequently, (1) a conventional distance 
sampling (Buckland et al. 2001) estimate is reported for the summers of 2004 and 2005, while (2) a model-based abundance estimator using generalised additive models (GAMs; Williams et al. 2006) was used to estimate mean abundance during the summers of 2004 to 2006 inclusive. These 2 statistical approaches are referred to subsequently as 'conventional' and 'model-based' abundance estimators. Search effort (trackline covered) and sighting locations used in the analyses (i.e. those from the summers of 2004 to 2006) are shown in Fig. 1. Note that the term 'Queen Charlotte Basin' refers to the broad region from northern Vancouver Island to the northern extent of our study area and is based on shared geological features, but also refers to the stratum of the same name in the original survey design (Thomas et al. 2007). Within the wider Queen Charlotte Basin, there is an open body of water called Queen Charlotte Sound, between northern Vancouver Island and southern Haida Gwaii (see Fig. 1).

The observation team consisted of 2 observers standing on a ship with binoculars scanning at $90^{\circ}$ on either side of the ship's bow and a data recorder. When a sighting was made, the observer and data recorder noted radial distance, radial angle (measured using angle boards), time, location, species or detailed comments about distinguishing features, and number of sharks. Radial distance estimates were corrected using correction factors calculated from observer-specific distance estimation experiments, in which observers' judged distances were regressed on true distances (Williams \& Thomas 2007, Williams et al. 2007).

Analysis of line-transect survey data. Distance sampling methods estimate density of animals through estimation of the strip width covered along a transect line (Buckland et al. 2001). Perpendicular distance data were right-truncated by 5 to $10 \%$, and 2 standard detection function models (Buckland et al. 2001) were fitted to the data using the software Distance 6.0 (Thomas et al. 2010). Animal density ( $\hat{D}$, the number of animals per unit area) was estimated by

$$
\hat{D}=\frac{n \cdot \hat{f}(0) \cdot \hat{E}(s)}{2 L}
$$

where: $n$ is the number of schools observed within truncation distance of the trackline; $\hat{f}(0)$ is the estimated probability density function of perpendicular distances, evaluated at zero distance (and is the reciprocal of the effective strip half-width); $\hat{E}(\mathrm{~s})$ is the estimated mean school size; and $L$ is the total length of trackline.

The 2 candidate models for the detection function were the half-normal and hazard-rate models (Buckland et al. 2001). The half-normal function (Eq. 2) models the probability of detecting an animal (or school) at perpendicular distance $x$ as:

$$
p(x)=\exp \left[\frac{-x^{2}}{2 \sigma^{2}}\right]
$$

where $\sigma^{2}$ is a parameter to be estimated. The hazard rate function (Eq. 3) models the probability of detecting an animal at perpendicular distance $x$ as:

$$
p(x)=1-\exp \left[-\left(\frac{x^{2}}{\theta_{1}}\right)^{-\theta_{2}}\right]
$$

where $\theta_{1}$ and $\theta_{2}$ are parameters to be estimated.

In the conventional distance-sampling analysis, survey design in 2004 and 2005 ensured that shark density measured along a grid of transects was representative of that in the study area as a whole. For completeness and for comparison with density estimates for other taxa (Williams \& Thomas 2007), density was calculated both in Queen Charlotte Basin (the stratum in which all shark sightings were made), and in the south coast and mainland inlet waters, which were surveyed but did not yield any sightings.

In the model-based analysis, a spatially explicit model was used to account for the non-systematic placement of tracklines surveyed in 2006 using methods described previously (Hedley et al. 1999, Williams et al. 2006). A descriptive GAM was constructed from effort and sightings data; the model was used to predict shark density at each spatial location in the survey region, and numerical integration of the density estimates provided an estimate of total shark abundance. Effort and sightings data were modelled using the 'count' method for interpolating density between tracklines (Hedley et al. 1999), in which probability of encountering a shark along a 1 nautical mile (nmi) segment of trackline was modelled as a 2-dimensional tensor product smooth function of latitude and longitude (Wood 2006), a 1-dimensional smooth spline of water depth, and an offset term for the area effectively searched in each segment. GAMs were fitted using the Density Surface Modelling engine packaged in the program Distance 6.0 (Thomas et al. 2010). The model framework was of the form:

$$
E\left(n_{i}\right)=\exp \left[\ln \left(21_{i} w_{i} \hat{p}_{i}\right)+\beta_{0}+\sum_{k} f_{k}\left(z_{i k}\right)\right]
$$

where: $n_{i}$ is the number of detected schools in the $i$ th segment; $l_{i}$ is the length of the $i$ th segment; $w_{i}$ is the truncation distance of the $i$ th segment; $\hat{p}_{i}$ is the estimated probability of detection of a school in the ith segment; $\beta_{0}$ is a parameter to be estimated; and $z_{i k}$ represents the value of the $k$ th explanatory spatial variable in the ith segment, which is a smooth function, $f_{k^{\prime}}$ of the explanatory variable.

After fitting a descriptive model, a gridded $\left(4 \mathrm{nmi}^{2}\right.$ or $13.7 \mathrm{~km}^{2}$ ) data set was passed to the descriptive model. The output of the model was a predicted density of 
sharks in each grid cell. A nonparametric bootstrap was performed to combine the detection function fitting, size bias regression, spatial modelling, model prediction and abundance estimation steps outlined above. For the bootstrap analysis, 499 bootstrap resample data sets were generated by sampling transect lines with replacement.

Species identification. After the survey was completed, 3 observers compared independently the descriptions of each sighting recorded in the field notes to a published field guide of sharks likely to be found in the region (DeMaddalena et al. 2007). Observers were instructed to pay particular attention to body size, shape and colour; and at a minimum to record number, shape and position of fins visible at the surface. The dorsal fins of the 2 species (salmon shark and blue shark) are similar in size but the salmon shark's is bulkier in appearance, with a more rounded high point, and set forward (more anterior), closer to the head. The blue shark's dorsal fin is more pointed at the high point, and set more over the middle, over the length, closer to the caudal fin. The caudal fin often projects above the water behind the dorsal fin. Each sighting was assigned a tentative species identity. Salmon shark abundance in the population (i.e. study area) was assumed to comprise the same proportion of overall abundance as its proportion of the sample (i.e. sighting records).

\section{RESULTS}

A total of $3377 \mathrm{nmi}(6254 \mathrm{~km})$ of trackline was surveyed. Field effort included data collected from: 6 to 21 June and 4 July to 15 August 2004, 1 to 29 August 2005, and 2 to 19 August and 24 to 29 September 2006. A total of 104 shark sightings were recorded during the survey, which is well above the 60 to 80 sightings typically recommended for fitting a detection function (Buckland et al. 2001). A truncation distance of $80 \mathrm{~m}$ was chosen, and AIC (Akaike's information criterion) favoured the hazard rate model ( $\triangle \mathrm{AIC}$ 3.73). Most sightings were of lone animals, but occasional sightings of 2 animals brought the mean group size to 1.01 individuals.

The observed concentration of sharks (Fig. 1) was located at the shelf break over the heads of submarine canyons, such as Moresby Trough, over adjacent banks of western
Queen Charlotte Sound (i.e. the open-water section of the broader Queen Charlotte Basin, between southern Haida Gwaii and northern Vancouver Island), such as Goose Banks, and extending eastward about halfway across the continental shelf towards the numerous coastal fjords surrounding Campbell Island and Bella Bella communities. Two smaller aggregations were
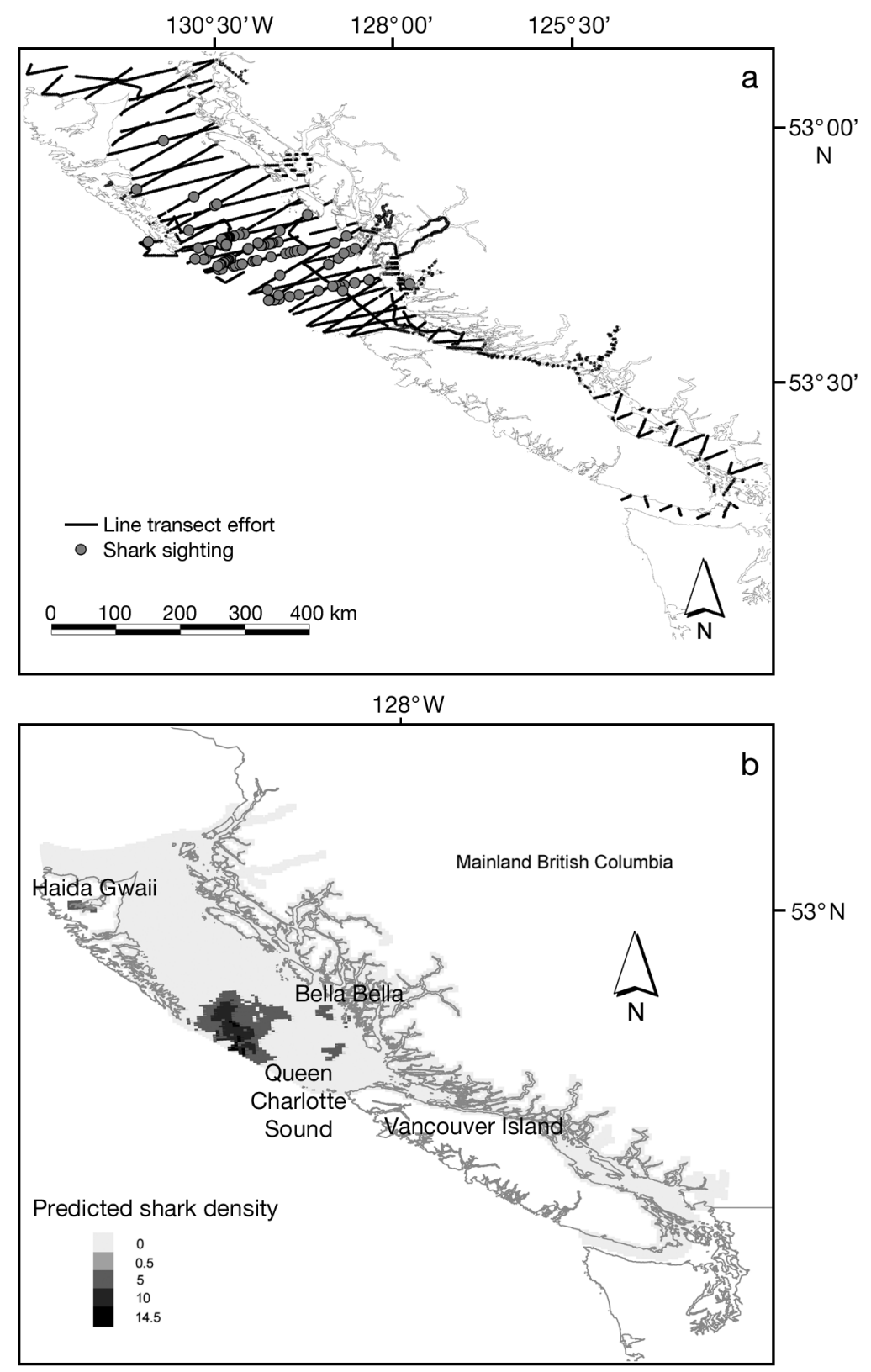

Fig. 1. (a) Search effort (black line) and shark sightings (filled grey circles) during 2004 to 2006 surveys. The survey was also repeated in spring 2007, but no sharks were seen. (b) Shark density (ind. per square nautical mile) in each cell in a grid overlaid across the study area, as predicted from the generalised additive model. Note the highest-density region (the 'hotspot') predicted at the western edge of Queen Charlotte Sound, centred on Moresby Trough 
located closer to the inner coastline of central BC (Fig. 1). The seaward extent of this aggregation is unknown, as the survey area did not extend seaward off the continental shelf break.

Abundance estimates of sharks in the study area are shown in Table 1. The conventional distance-sampling method produced an estimate of 31200 sharks at the surface in the entire study area on average during the summer surveys (95\% CI: 15900 to 61300). The model-based abundance estimate predicted from the selected model was 26900 sharks (95\% CI: 19600 to $37000)$. In both cases, the number of animals at depth is not known, as this concentration of sharks was indicated only by surface observations, and consequently represents a minimum estimate of abundance of all surface-oriented sharks in the area at the time of the survey. The high-density region (the 'aggregation') shown in Fig. 1b spanned an area approximately 2500 $\mathrm{nmi}^{2}$, thereby covering approximately $10 \%$ of the $24664 \mathrm{nmi}^{2}$ survey region.

Approximately $70 \%$ of sightings were given a tentative species identification. Of these, salmon sharks were the most commonly observed species $(63 \%$ of those sightings identified to species), followed by blue sharks (15\% of those identified to species). A sighting was typically scored as a salmon shark when observers recorded a relatively large dorsal fin, or a dark grey dorsal surface with light ventral surface, or both. Blue sharks were identified from records noting a dark blue colour and slender body. The remaining observations could not be identified to species. While there was considerable disagreement among observers about the identity of some observations, there was broad agreement across observers that salmon sharks were the dominant species sighted, with estimates of 50,68 and $70 \%$ of sightings being scored as salmon sharks by the 3 observers. Our best estimate is that $44 \%$ of the surface-oriented sharks in the study area (i.e. $63 \%$ of $70 \%$ ) were salmon sharks, but the true proportion could be much higher.

Table 1. Summary of density and abundance estimates from conventional and model-based (generalised additive model) distance-sampling abundance estimators. The Queen Charlotte Basin stratum (Fig. 1) is the region common to all 4 surveys (summers of 2004 to 2006 and spring 2007), while the entire survey region includes adjacent fjords and south coast waters in which no sharks were seen. nmi: nautical miles

\begin{tabular}{|lccc|}
\hline & $\begin{array}{c}\text { Density } \\
\left(\mathrm{n} \mathrm{nmi}^{-2}\right)\end{array}$ & $\begin{array}{c}\text { Abundance } \\
(\mathrm{n}) \text { Mean }\end{array}$ & 95\% CI \\
\hline Conventional distance-sampling estimate & & & \\
Queen Charlotte Basin, 2004 & 0.854 & 15800 & $6300-39000$ \\
Queen Charlotte Basin, 2005 & 2.592 & 47600 & $22100-102000$ \\
Queen Charlotte Basin, 2004-2005 & 1.701 & 31200 & $15900-61200$ \\
Survey region, 2004-2005 & 1.283 & 31200 & $15900-61300$ \\
Model-based abundance estimate & & & \\
Survey region, 2004-2006 & 1.091 & 26900 & $19600-37000$ \\
\hline
\end{tabular}

\section{DISCUSSION}

Our data indicate that at least 10000 pelagic sharks were concentrated in an approximately $2500 \mathrm{nmi}^{2}$ section of the Queen Charlotte Basin during the summers of 2004 to 2006. Approximately half of these were likely to be salmon sharks, but future dedicated shark surveys need to be designed specifically to focus on species identification. In the present survey, which was designed for marine mammals, (1) there was strong inter-observer agreement that salmon sharks were the most commonly identified shark species, (2) few other species of large pelagic sharks occur in the region in this way, and (3) those that do are unlikely to be confused with salmon sharks (DeMaddalena et al. 2007). It is important to place this new information in the context of the present paper's primary aim, which is to provide an estimate of the right order of magnitude for a guild of predators that has received little scientific attention in this region previously. The distribution data are as important a finding as the abundance data. The abundance estimates are necessarily coarse and tentative, and are intended only as a starting point for setting priorities for future research efforts. No attempt was made to correct the abundance estimates for the proportion of time that sharks spend at the surface (cf. Campana et al. 2008). The number of sightings is appropriate for generating an abundance estimate from line-transect survey data (Buckland et al. 2001), but improvement is needed in terms of apportioning total abundance by species, and evaluating how abundance and distribution change seasonally and annually. In the meantime, these initial estimates are reported with some strong caveats about their limitations and large associated confidence intervals.

Our observations and estimates are in line with other research results concerning salmon sharks, their Atlantic congener, the porbeagle shark Lamna nasus, the Atlantic blue shark Prionaca glauca, and the same species observed elsewhere in the eastern Pacific. The porbeagle migration pattern across the North Atlantic involves main nursery areas in the eastern North Atlantic, foraging areas in the western North Atlantic, and movement between them (Aires-da-Silva \& Gallucci 2007). The porbeagle pattern in the western North Atlantic includes spring migration to Georges Bank and the Gulf of Maine in January and February and movement in the spring to south Newfoundland and the Gulf of St. Lawrence in the autumn. Mating occurs in the 
autumn and parturition in the spring (Gibson \& Campana 2005, Pade et al. 2009). These patterns are consistent with tagging data for migratory sharks (Hulbert \& Rice 2002, Hulbert et al. 2005, Weng et al. 2005, 2008, Okey et al. 2007). No sharks were seen when the survey was conducted in spring 2007, which lends support to the notion that this aggregation peaks seasonally. We have no other evidence to indicate that this shark concentration is present during seasons other than summer and early autumn.

Explanations for this concentration of sharks include foraging, resting and reproduction. These sharks may concentrate in this area during July and August to intercept adult salmon on their return migration from the North Pacific Ocean to natal streams in the region. For instance, salmon returning to the Fraser River-the largest of Canadian salmon runs-use this more northerly route through Queen Charlotte Sound and Johnstone Strait during times of higher-than-normal sea temperatures (Thomson et al. 1994, Healey 1998), and they use the more southern route through the Strait of Juan de Fuca when sea temperatures are colder. Sea temperatures at nearby Stn P have been increasing since the late 1950s (Whitney \& Robert 2007), thus making it increasingly likely that returning salmon return consistently through Queen Charlotte Sound. The position of the observed shark concentration in the western Queen Charlotte Sound would indeed be the expected position for intercepting Pacific salmon as they come onto the continental shelf during warm-water regimes. If salmon sharks have been increasing or concentrating more in the North Pacific for any one of a variety of reasons (Okey et al. 2007), and especially during the most recent part of this overall warming temperature trend, then it follows that salmon shark predation may be an increasingly important source of mortality for returning $\mathrm{BC}$ salmon stocks, especially if return routes are consistent and predictable.

The shark concentration could also be explained by factors that have little to do with salmon, namely the notion that this area is more productive in general than the adjacent areas surveyed. For example, northern elephant seals Mirounga angustirostris (Phocidae), Pacific white-sided dolphin Lagenorhynchus obliquidens (Delphinidae) and ocean sunfish Mola mola (Molidae) were also mostly concentrated in this same general hotspot area, and fin whales Balaenoptera physalus (Balaenopteridae) and humpback whales Megaptera novaeangliae (Balaenopteridae) were found in high numbers in this area as well as at a site just slightly to the north of this area (Williams \& Thomas 2007, R. Williams pers. obs.). The density we report for sharks in the Queen Charlotte Basin is comparable to that reported previously for Pacific white- sided dolphins in the area, and for harbour seals Phoca vitulina in BC's southern Strait of Georgia (Williams \& Thomas 2007). Similarly, the density and abundance estimates presented here are plausible, given those reported for salmon sharks elsewhere: densities of $>10$ salmon sharks $\mathrm{km}^{-2}$ have been observed in Prince William Sound in July and August (Hulbert et al. 2005, V. F. Gallucci pers. obs.) as salmonids return to spawning streams. Using catch per unit effort methods, Nagasawa (1998) estimated that there were 2000000 salmon sharks in the entire North Pacific, including 94000 in the Gulf of Anadyr, 122000 in the western Bering Sea and 153000 in southern Okhotsk Sea. There are a number of geographic, hydrographic and oceanographic interfaces and other features in this area that make it particularly productive and ecologically unique, and that may support locally high densities of salmon sharks. We consider heightened overall productivity to be a reasonable alternative to the salmon-interception explanation for the observed shark concentration. This productivity explanation still implies a feeding function of this shark aggregation, which has implications for the preferred late summer prey of salmon sharks in such coastal settings, the bulk of which is Pacific salmon species in rough proportion to their local occurrence (Nagasawa 1998, Brodeur et al. 1999, Hulbert et al. 2005). But salmon sharks also consume sablefish Anoplopoma fimbria (Anoplopomatidae), squid (Teuthoidea), rockfishes (Sebastes spp., Sebastidae), Pacific herring Clupea pallasii pallasii (Clupeidae), and other prey (Hulbert et al. 2005), all of which are available in the area.

The idea that this location of shark concentration represents a summertime resting area for migrating sharks of the northeast Pacific is also consistent with available evidence (Weng et al. 2005, their Fig. S1B), but it is known that these sharks actively feed on salmon in this and other northeast Pacific settings in summer. This concentration could serve both functions (i.e. resting and feeding) if these sharks can reduce their energy expenditure while preying upon migrating salmon. It is also possible that the observed shark concentration serves as a mating aggregation, but we know of no specific evidence relating to this explanation for this area.

Some evidence for recent increases in salmon shark populations in the northeast Pacific Ocean were recently presented with some alternative explanations for these observed patterns (Okey et al. 2007), including northern distributional shifts due to increases in ocean temperatures, population rebound since the 1992 banning of high-seas drift gillnets, and indirect effects of fisheries on competing pelagic predators. These explanations could explain the shark concentration documented herein, but this observed concentration might not be new. Although local sport-fishing 
guides indicate a sudden appearance of abundant salmon sharks, it is possible that it has been a persistent but unreported feature of this area that has gone undetected.

If this shark concentration is new, it may be an indicator of indirect ecological impacts of climate variability or change. A warming ocean could enable the development of an effective 'feeding gauntlet' at the northern return route for Fraser River salmon, if indeed a warming ocean climate regime favours the exclusive use of that northern route (e.g. Thomson et al. 1994, Healey 1998).

Shark species are highly diverse and the majority are considered highly vulnerable to overexploitation (i.e. by directed fisheries or bycatch) due to their slow growth, slow reproduction, low fecundity, and other life-history characteristics (e.g. Bonfil 1994, Fowler et al. 2002, Dulvy et al. 2008). Salmon sharks are already a management issue in the region, as they are regularly captured as bycatch in BC's groundfish fisheries, and our results contribute useful data to assess the relative risk of fishing mortality on this shark species. For instance, research that identifies and subsequently targets hotspots of such important biological features will make future studies more cost-effective, efficient and able to produce more precise abundance estimates than single-stratum surveys (Buckland et al. 2001). However, considerably more information is needed on this and other shark species in order to understand the role of such potentially important predators on Pacific salmon stocks and other components of the biological community, and to ensure the conservation, sustainability and integrity of functioning and resilient Pacific marine ecosystems. The ecological importance of top predators in marine ecosystems, from marine mammals to sharks, is naturally coupled with the importance of salmon in these ecosystems, which is in turn coupled with both the cultures and economies of the Pacific Northwest. It is therefore surprising that more is not known about sharks in the region. At-sea predation on salmon generally as well the specific role of salmon sharks are both in need of further study. The direction of the literature is towards filling this void, because more papers on these sharks have been published since 2000 than in the previous 50 yr. The present paper is intended as a contribution to the literature of unravelling these interactions, and a priority-setting exercise to guide much-needed future research.

Acknowledgements. Data on shark abundance and distribution were collected during a marine mammal survey conducted by R.W. in partnership with Raincoast Conservation. We thank the field observers, crew and funders for assistance with data collection. We thank L. Thomas for assistance with survey design and data analysis. Species identification was conducted by R.W., T.A.O. and O. Andrews, with additional input from E. Ashe, A. De Maddalena, S. Heinrich, M. MacDuffee, I. McAllister and R. Stewart. R.W.'s contribution at the writing stage was supported by a Canada-US Fulbright Visiting Research Chair at the University of Washington. T.A.O.'s contributions were supported by a Pew Fellowship in Marine Conservation, a programme of the Pew Environment Group of the Pew Charitable Trusts, and by the Conservation Science Institute. B. Wright provided advice on salmon shark behaviour at early stages of manuscript development. We thank the anonymous reviewers and the editor, Professor Rory Wilson, for valuable feedback on earlier versions of the manuscript.

\section{LITERATURE CITED}

Aires-da-Silva A, Gallucci V (2007) Demographic and risk analyses applied to management and conservation of the blue shark (Prionace glauca) in the North Atlantic Ocean. Mar Freshw Res 58:570-580

> Battin J, Wiley MW, Ruckelshaus MH, Palmer RN, Korb E, Bartz KK, Imaki H (2007) Projected impacts of climate change on salmon habitat restoration. Proc Natl Acad Sci USA 104:6720-6725

BCME (BC Ministry of Environment) (2007) Environmental trends in British Columbia: 2007. BC Ministry of Environment, Victoria (available at www.env.gov.bc.ca/soe/et07/)

BCMWALP (BC Ministry of Water, Land and Air Protection) (2002) Indicators of climate change for British Columbia, 2002. Water, Air and Climate Change Branch, BC Ministry of Water, Land and Air Protection, Victoria

Bonfil R (1994) Overview of world elasmobranch fisheries. FAO Fish Tech Pap No. 341. FAO, Rome

Brodeur R, McKinnell S, Nagasawa K, Pearcy W, Radchenko V, Takagi S (1999) Epipelagic nekton of the North Pacific subarctic and transition zones. Prog Oceanogr 43:365-397

$>$ Brodeur RD, Ralston S, Emmett RL, Trudel M, Auth TD, Phillips AJ (2006) Anomalous pelagic nekton abundance, distribution, and apparent recruitment in the northern California Current in 2004 and 2005. Geophys Res Lett, 33, L22S08, doi:10.1029/2006GL026614

Buckland ST, Anderson DR, Burnham KP, Laake JL, Borchers DL, Thomas L (2001) Introduction to distance sampling: estimating abundance of biological populations. Oxford University Press, New York, NY

Campana SE, Brazner J, Marks L, Joyce W and others (2008) Status of basking sharks in Atlantic Canada. Canadian Science Advisory Secretariat (CSAS) Res Doc 2008/004, CSAS, Dartmouth, NS

Crozier LG, Zabel RW, Hamlett AF (2008) Predicting differential effects of climate change at the population level with life-cycle models of spring Chinook salmon. Glob Change Biol 14:236-249

DeMaddalena A, Preti A, Polansky T (2007) Sharks of the Pacific Northwest: including Oregon, Washington, British Columbia and Alaska. Harbour Publishing, Madeira Park, $\mathrm{BC}$

Dulvy NK, Baum JK, Clarke S, Compagno LJV and others (2008) You can swim but you can't hide: the global status and conservation of oceanic pelagic sharks and rays. Aquat Conserv Mar Freshw Ecosyst 18:459-482

Eggers DM, Irvine JR, Fukuwaka M, Karpenko VI (2005) Catch trends and status of North Pacific salmon. North Pacific Anadromous Fish Commission (NPAFC) Doc. No. 723, Rev. 3, NPAFC, Vancouver, BC 
Fowler SL, Reed TM, Dipper F (eds) (2002) Elasmobranch Biodiversity, Conservation and Management: Proc Int Seminar and Workshop, Sabah, Malaysia, July 1997. The World Conservation Union (IUCN), Gland

Gallucci VF, Foy RJ, O'Brien SM, Aires-Da-Silva A and others (2008) Information from a pregnant salmon shark Lamna ditropis in the eastern North Pacific with observations on oophagous reproduction. J Fish Biol 73:732-739

Gibson AJF, Campana SE (2005) Status and recovery potential of porbeagle shark in the Northwest Atlantic. Canadian Science Advisory Secretariat (CSAS) Res Doc 2005/53, CSAS, Dartmouth, NS

Goldman KJ (2003) Aspects of age, growth, demographics and thermal biology of two Lamniform shark species. $\mathrm{PhD}$ dissertation, Virginia Institute of Marine Science, Williamsburg, VA

Groot C, Margolis L (1991) Pacific salmon life histories. UBC Press, Vancouver, BC

Healey CG (1998) On the use of perceptual cues and data mining for effective visualization of scientific datasets. In: Davis WA, Booth KS, Fournier A (eds) Proc Graphics Interface 1998 Conf, Jun 18-20 1998, Vancouver. Canadian Human-Computer Communications Society, p 177-184

Hedley SL, Buckland ST, Borchers DL (1999) Spatial modelling from line transect data. J Cetacean Res Manag 1: 255-264

Hilborn R (1992) Hatcheries and the future of salmon in the northwest. Fisheries 17:5-8

Hulbert LB, Rice SD (2002) Salmon shark, Lamna ditropis, movements, diet, and abundance in the eastern North Pacific Ocean and Prince William Sound, Alaska. Report No. 02396, Exxon Valdez Oil Spill Restoration Project 02396 Final Report, NOAA Fisheries Auke Bay Laboratory, Juneau, AK

Hulbert LB, Aires-Da-Silva AM, Gallucci VF, Rice JS (2005) Seasonal foraging movements and migratory patterns of female Lamna ditropis tagged in Prince William Sound, Alaska. J Fish Biol 67:490-509

Krkosek M, Lewis MA, Morton A, Frazer LN, Volpe JP (2006) Epizootics of wild fish induced by farm fish. Proc Natl Acad Sci USA 103:15506-15510

Krkosek M, Ford JS, Morton A, Lele S, Myers RA, Lewis MA (2007) Declining wild salmon populations in relation to parasites from farm salmon. Science 318:1772-1775

Nagasawa K (1998) Predation by salmon sharks (Lamna ditropus) on Pacific salmon (Oncorhynchus spp.) in the North Pacific Ocean. North Pac Anadromous Fish Comm Bull $1: 419-433$

NRC (National Research Council) (1996) Upstream: salmon and society in the Pacific Northwest. National Academy Press, Washington, DC

Okey TA, Wright BA, Brubaker MY (2007) Salmon shark con-

Editorial responsibility: Rory Wilson,

Swansea, UK nections: North Pacific climate change, indirect fisheries effects, or just variability? Fish Fish 8:359-366

Pade N, Queiroz N, Hunphries N, Will M, Jones C, Noble L, Sims DW (2009) First results from satellite-linked archival tagging of porbeagle shark: area fidelity, wider scale movements and plasticity in diel depth-changes. J Exp Mar Biol Ecol 370:64-74

Stevens J (2005) Prionace glauca. In: IUCN red list of threatened species, Version 2010.1 (available at www.iucnred list.org, accessed 22 April 2010)

Thomas L, Williams R, Sandilands D (2007) Designing line transect surveys for complex survey regions. J Cetacean Res Manag 9:1-13

Thomas L, Buckland ST, Rexstad EA, Laake JL and others (2010) Distance software: design and analysis of distance sampling surveys for estimating population size. J Appl Ecol 47:5-14

Thomson KA, Ingraham WJ, Healey MC, Leblond PH, Groot C, Healey CG (1994) Computer simulations of the influence of ocean currents on Fraser River sockeye salmon (Oncorhynchus nerka) return times. Can J Fish Aquat Sci 51:441-449

- Waples RS (1999) Dispelling some myths about hatcheries. Fisheries 24:12-21

> Weng KC, Castilho PC, Morrissette JM, Landeira-Fernandez AM and others (2005) Satellite tagging and cardiac physiology reveal niche expansion in salmon sharks. Science 310:104-106

> Weng KC, Foley DG, Ganong JE, Perle C, Shillinger GL, Block BA (2008) Migration of an upper trophic level predator, the salmon shark Lamna ditropis, between distant ecoregions. Mar Ecol Prog Ser 372:253-264

Whitney F, Robert M (2007) Ocean observations from Line P and Skaugran surveys. In: State of the Pacific Ocean 2006. DFO Canadian Science Advisory Secretariat (CSAS) Sci Advis Rep 2007/019, Vancouver, BC, p 29-30

Williams R, Thomas L (2007) Distribution and abundance of marine mammals in the coastal waters of British Columbia, Canada. J Cetacean Res Manag 9:15-28

Williams R, Thomas L (2009) Cost-effective abundance estimation of rare animals: testing performance of small-boat surveys for killer whales in British Columbia. Biol Conserv 142:1542-1547

Williams R, Hedley SL, Hammond PS (2006) Modeling distribution and abundance of Antarctic baleen whales using ships of opportunity. Ecol Soc 11:1 (available at www.ecologyandsociety.org/vol11/iss1/art1/)

Williams R, Leaper R, Zerbini AN, Hammond PS (2007) Methods for investigating measurement error in cetacean linetransect surveys. J Mar Biol Assoc UK 87:313-320

Wood SN (2006) Generalized Additive Models: an introduction with R. Chapman \& Hall/CRC

Submitted: December 11, 2008; Accepted: June 29, 2010

Proofs received from author(s): August 19, 2010 